\title{
AUTOMATED GIS-BASED TECHNIQUE FOR EVALUATION OF INDIRECT GROWING SEASON ESTIMATIONS
}

\author{
I. Rykin ${ }^{1}$, E. Panidi ${ }^{1}$, V.Tsepelev ${ }^{2}$ \\ ${ }^{1}$ Department of Cartography and Geoinformatics, Saint Petersburg State University, St. Petersburg, Russia - \\ ivan.rykin94@gmail.com, panidi@ya.ru, e.panidi@spbu.ru \\ ${ }^{2}$ Meteorological Department, Russian State Hydrometeorological University, St. Petersburg, Russia - v0010200@mail.ru
}

Commission IV, WG IV/4

KEY WORDS: GIS, Remote Sensing, MODIS, NDWI, Climate Change, Growing Season, Vegetation

\begin{abstract}
:
This article is based on NDWI (Normalized Difference Water Index) which is automatically computed from the daily MODIS data. The main purpose of the article is to tell how the evaluation of NDWI-based growing season estimations can be automated. The NDWI is used as an indicator of liquid water quantity in vegetation, which is less sensitive to atmospheric scattering effect then the famous growing index (NDVI). The NDWI is computed using cloud-based platform (Google Earth Engine was applied) and compared with the daily meteorological data. The available meteorological data is collected for the past 130 years and NDWI data is collecting for the past 20 years. An automated technique has been probated on the example of republic of Komi, as it has a different climate forming factors. This approach can be used to evaluate growing season estimations for other territories that contain vegetation. Due to the accumulated amount of data, the study is relevant and has a special significance for areas with sparse hydrometeorological network.
\end{abstract}

\section{INTRODUCTION}

Climate is a rapidly changing environment, which is influenced by many factors. Therefore, vegetation is a biological indicator, which can register changes in the environment. Today, satellite data is used for monitoring some changes in vegetation. Different spatial and temporal resolution can be used for a comprehensive research. In this paper the automated cloud-GISbased technique for estimating the computed growing seasons is shortly described. As the computations are provided with oneday time resolution, the data amounts become huge. Cloudbased approach helps to reduce computation time. The growing season analysis is carried out according to ground observations and remote sensing data. According to the (USSR climate reference book..., 1968), the growing season is defined as the transition of the surface air temperature through threshold of +5 and $+10{ }^{\circ} \mathrm{C}$. However, in some areas where there is no well spread meteorological network, the daily graphs of the normalized difference water index (NDWI) can be used (Panidi et al, 2018; Panidi et al, 2019). Where absolute minimums are the boundaries of the beginning and end of the growing season. The main idea of the work is to create an automated technique that allows to evaluate accuracy of indirect NDWI-based estimations of growing season time frames with one-day time resolution using the open source software.

\section{STUDY AREA}

The republic of Komi is located in the northeast part of Russia. This region was chosen because of its climate-forming factors (orography, the presence of wetlands, dense river network) and of its evenly coverage by meteorological stations. Permafrost and the sea closeness play a great role as formers of the regional climate.

\section{INITIAL DATA}

The processed data include ground observations and remote sensing data. Ground observations consist of the daily averaged surface air temperature and daily precipitation values for the past 59 - 130 years for 10 meteorological stations from the open AISORI database (http://aisori-m.meteo.ru/waisori/).

\begin{tabular}{|c|c|c|}
\hline $\begin{array}{c}\text { Meteorological station IDs } \\
\text { and names }\end{array}$ & $\begin{array}{c}\text { Observation } \\
\text { period }\end{array}$ & $\begin{array}{c}\text { Observation } \\
\text { length (years) }\end{array}$ \\
\hline Elezkaja (23220) & $1959-2018$ & 59 \\
\hline Petrun (23324) & $1904-2018$ & 114 \\
\hline Ust-Tsylma (23405) & $1892-2018$ & 126 \\
\hline Ust-Usa (23412) & $1936-2018$ & 82 \\
\hline Pechora (23418) & $1943-2018$ & 75 \\
\hline Irael (23514) & $1959-2018$ & 59 \\
\hline Ust-Vum (23707) & $1959-2018$ & 59 \\
\hline Troitsko-Pechorsk (23711) & $1888-2018$ & 130 \\
\hline Syktyvkar (23804) & $1888-2018$ & 130 \\
\hline Koigorodok (23904) & $1959-2018$ & 59 \\
\hline
\end{tabular}

Table 1. Republic of Komi meteorological stations

The remote sensing data is collected by the TERRA satellite with the MODIS sensor for the past 20 years. In our project we use the MOD09GA product (https://lpdaac.usgs.gov/products/mod09gav006/).

The MOD09GA product provides a daily surface reflectance at $500 \mathrm{~m}$ resolution. Due to the development of cloud computing,

\footnotetext{
* Corresponding author
} 
now there is no problem for calculating huge array of satellite data. Therefore, the main instrument, which combines a multipetabyte catalog of satellite imagery and geospatial datasets for cloud calculations, is a Google Earth Engine. The Earth Engine has a code editor at (https://code.earthengine.google.com), which is a web-based integrated development environment (IDE) for the Earth Engine JavaScript application programming interface (API).

\section{METHODS AND COMPUTATIONS}

The NDWI is calculated by the Gao's formula (Gao, 1996), using surface reflectance channels (sur_refl_b02 and sur_refl_b05) of MOD09GA. For example, there will be a several steps how the NDWI can be calculated for validation. The first step for validation is to calculate the NDWI for the whole Komi region for every day from 2000 to 2019.

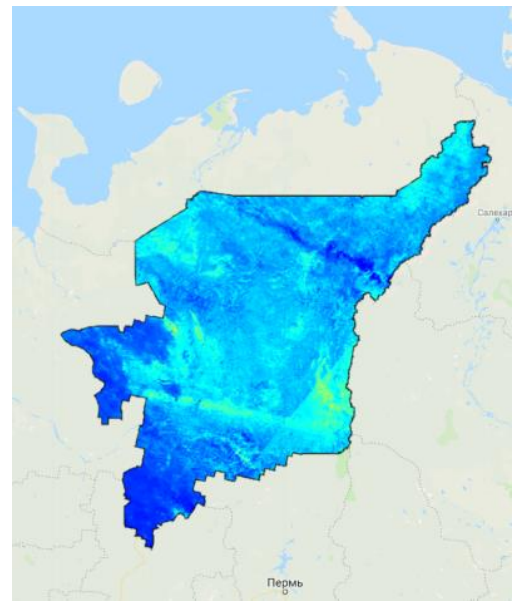

Figure 1. NDWI map for the republic of Komi (2000-03-01)

The second step is to create cloud mask from the state_ $1 \mathrm{~km}$ band, reading $0-1$ bits, if $0-1$ bits are equal 01 , it means that there is a cloud pixel, according to the User's Guide (Vermote, 2011). Other needed masks (e.g., vegetation mask) are applied at this step.

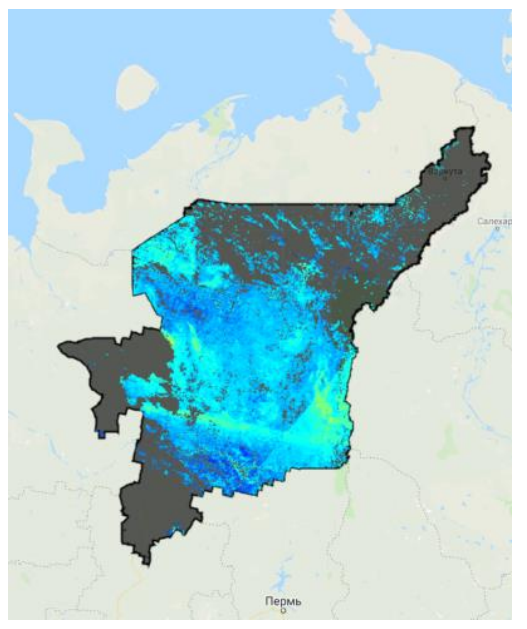

Figure 2. NDWI map for the republic of Komi with a cloud mask effect (2000-03-01)
The third step is to create a $10 \mathrm{~km}$ buffer zone around the meteorological station with a cloud mask effect. According to the Guidance documents (Guide to Meteorological Instruments and Methods of Observation, 2006; Guidance document, 2011), the buffer zone is equal $10 \mathrm{~km}$, because this value has a positive effect on the representativeness of a meteorological observation.

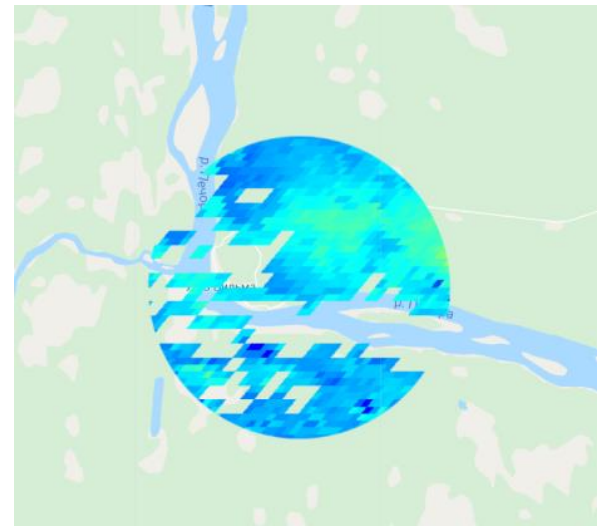

Figure 3. NDWI map for the $10 \mathrm{~km}$ buffer zone around the UstTsylma meteorological station with a cloud mask effect (200003-01)

The fourth step is to compute the average NDWI value for each buffer zone. All the steps are repeated for every MOD09GA dataset to produce annual graph of the NDWI for the selected meteorological station. Produced graphs are compared with the graphs of daily averaged surface air temperature to find the similar days of the beginning and ending the growing seasons.

\section{RESULTS}

We designed the technique to automate evaluation of growing season estimations, which are based on indirect approach. The problem resolved was consisted in huge amounts of data needed to be processed to collect statistics on growing season time frames estimation. The direct approach is based upon meteorological data with long-term series of observations. The indirect is based on long-term satellite observation series. The advantage of the method which is based on satellite data, consists in higher spatial resolution, therefore, the problems associated with the density and location of hydrometeorological stations are eliminated. In addition, using remote sensing data, it is possible to carry out work on the space-time analysis of the dynamics of changes in the framing dates of growing seasons (spring, summer, autumn), realizing the results of the assessment in the form of maps. At last, using the cloud computing is the fastest and easiest way to to process such huge datasets.

\section{ACKNOWLEDGEMENTS}

The MODIS Level 2GL datasets were retrieved from NASA LP DAAC at the USGS EROS Center https://pdaac.usgs.gov/products/mod09gav006/ and computed in Google Earth Engine using code editor at https://code.earthengine.google.com.

Ground observations data were retrieved from Waisori Web interface, courtesy of the RIHMI-WDC of Roshydromet, Veselov V.M., Pribylskaya I.R., Mirzeabasov O.A. (http://aisori-m.meteo.ru/waisori/). 


\section{REFERENCES}

Gao, B.C., 1996. NDWI - A Normalized Difference Water Index for Remote Sensing of Vegetation Liquid Water From Space. Remote Sensing of Environment, 58 (3), 257-266.

Guidance document. Manual hydrometeorological stations and posts. Issue 10. Inspection of hydrometeorological stations and posts. Part I. Inspection of meteorological observers at stations. RD 52.04.666-2005, as of 2011.

Guide to Meteorological Instruments and Methods of Observation WMO-No. 8 Preliminary seventh edition. 2006. I,1.

Main Directorate of the Hydrometeorological Service under the Council of Ministers of the USSR (Northern Directorate of the Hydrometeorological Service, Arkhangelsk Hydrometeorological Observatory), 1968. USSR climate reference book, issue 1. Arkhangelsk and Vologda regions, Karelian and Komi ASSR. Part. 2. Air and soil temperature. Leningrad, Gidrometeoizdat. In Russ.

Panidi, E., Rykin, I., Nico, G., Tsepelev, V., 2019. Toward Satellite-Based Estimation of Growing Season Framing Dates in Conditions of Unstable Weather. In: El-Askary H., Lee S., Heggy E., Pradhan B. (eds) Advances in Remote Sensing and Geo Informatics Applications. Advances in Science, Technology \& Innovation (IEREK Interdisciplinary Series for Sustainable Development). Springer, Cham. doi.org/10.1007/978-3-03001440-7_31.

Panidi, E.A., Rykin, I.S., Tsepelev, V.Yu., 2018. Towards the issue of allocation of the time frames for growing seasons using ground observations and remote sensing data. Proceedings of the International conference "InterCarto/InterGIS". 24 (2), 129-140 doi.org/10.24057/2414-9179-2018-2-24-129-140. In Russ.

Vermote, E.F., 2011. MODIS Surface Reflectance User's Guide, version 1.3. 